\title{
Impact of Political Violence on the Socio- Economic Development of Yobe State, Nigeria
}

\author{
Adole Raphael Audu ${ }^{1}$, Dr. Mbaya Paul ${ }^{2}$, Aliyu Manpaa ${ }^{3}$ \\ ${ }^{1,2,3}$ Department of Public Administration Faculty of Management Science University of Maiduguri Borno State
} Nigeria

\begin{abstract}
This paper investigates political violence and its socio-economic consequences on the development of Yobe State particularly and Nigeria generally. To achieve this objective, the study uses both the primary and secondary sources of data collection. A sample of 500 respondents was selected and administered with questionnaire in six Local Government Areas of Yobe State through the simple random sampling techniques. The data obtained from the respondents were manually analyzed through percentage technique and cross tabulation. The Social Movement Theory (SMT) was used as the main theoretical framework for the study The results of the study revealed that poverty and unemployment are not the causes and motivations of political violence in Yobe State but rather, the causes of political violence in Yobe State was as a result of systemic leadership failure. Thus, the study recommends among others that political leaders should play a role in building effective government through their constitutional duties and mandates.
\end{abstract}

Keywords: Violence, Political violence, Socio-economic development, Yobe State,Nigeria

\subsection{Background to the Study}

\section{Introduction}

Violence has become a problem of great national and international concern because of its socioeconomic and political consequences. Through much of history violence has been the norm rather than an exception in relation among individuals and groups of people. As Pearson and Rochester (1984: 127 [1]) have rightly observed: "A murder is committed every twenty-six minutes on average in the United States of America (USA) and a violent crime of some sorts occur every forty minutes". Economic, social as well as political violence have been committed and are still committed in many other countries across the globe

According to Douglas (2003[2]) four years of mass genocide in the 1970s resulted in two million deaths across the globe. The Iran-Iraq war of the 1980s also left one million dead. The 1992-1995 war in Bosnia killed 200,000 and accounted for two million refugees, many of whom were terrorized and forced from their home regions in coordinated "ethnic cleansing" campaigns. Somalia, Rwanda, Sierra Leone, the Congo, Kosovo, Afghanistan, and Iraq in the past ten years, all of these places have become synonymous with violence.

Douglas (2003[3]) went further to add that in some conflicts, civilians have been mutilated as part of a deliberate strategy to demoralize communities and destroy their social structures. Prime examples are the civil wars in Mozambique and Sierra Leone, where many people had ears or lips severed by rebels. Genocides, rapes, mutilations, bombings, and famines have become the standard for countless persons caught in these senseless patters of violence. A fact which Gambari (2008[4]) clearly pointed that the reality has turned out to be different as the world has witnessed the emergence of conflicts of unique complexity in view of the social relations in States across the globe. It is observed that a considerable number of violent behaviour is inter -ethnic, intraethnic and inter-personal and it occurs within a society in the forms of riots, revolutions, protests, demonstrations, Coup de tats and civil wars. This point is illustrative of the high level of political violence that frequently erupts in societies across the globe. The very fact that politics is a game that determines the acquisition of power and control of resources as well as its allocation, the instinct and urge for political violence has become an inescapable reality in a social formation such as Nigeria.

Nigeria, like any other plural federal states has been characterized by incessant contestations among individuals, groups and the different ethnic groups that make up the federal union. Since the return to democratic rule on $29^{\text {th }}$ May, 1999, these contestations have increased in alarming and violent proportion across the country. According to Mohammed (2012: 1[5]) "some ethnic groups in Nigeria feel that the return to civilian rule has offered them the opportunity to agitate for what they belief is their right to possess, partake in or achieve their development". Thus, these competing groups achieve their political, economic and social objectives with dire consequences on the Nigerian polity. That is why various forms of aggressions are displayed on a daily basis in different parts of the country. For example, the activities of the Movement for the Emancipation of the Niger Delta (MEND), the Jama'atu Ahlis Sunnah Lidda'awati wal jihad (Boko Haram) and the activities of other geo-political nationalities in the country could be traced to the inability of some 
individuals or group of individuals to access the economic and political resources of the country. In fact since the country returned to democratic rule on 29th May 1999 the phenomenon of violence has assumed a serious dimension: Bombings, militancy, religious riots, vandalism, arsons, political assassinations and the like have become the main features of Nigeria's nascent democracy.

The scenario encapsulated above is not different from that of Yobe State. The State also stands out as a distinct point of intersection of individuals, groups and tribes competing for economic and political space. As a result of this, the state is now confronted with conflicts that have led to the destruction of lives and property as seen in the 2007, 2009 and 2011 political crises in the State. A close examination of the level of political violence in Yobe State has clearly shown that the State has virtually a tripled level of violence in the country.

This glaring and alarming circle of violence in the State has continued to remain an issue of grave concern to the State and Nigeria generally. Obviously, the spate of bomb blasts, kidnappings, vandalism and series of killings from 2009-2013 especially in Damaturu, Potiskum, Fika and Gaidam Local Government Areas of the State is quiet worrisome. Despite the assurance and measures taken for the protection of lives and property by the State Government, the security situation in the State has continue to deteriorate with huge impact on the socio-economic and political development of the State.

It is against this backdrop that the researchers are embarking on this study aimed at examining the consequences of the situation for the socio- economic development of Nigeria generally and Yobe State in particular.

\subsection{Research Objectives}

This aspect of the paper is to highlight the objectives of embarking on this study as such the following could be put forward as the main objectives of the study to:

i. examine the impact of political violence on the development of Yobe State and Nigeria generally;

ii. find out the causes and nature of political violence in Yobe State so as to proffer possible solutions.

\subsection{Significance of the Study}

This paper examines the socio-economic impact of political violence on the development of Yobe State. Thus, its significance lies in the fact that it aims at giving a coherent analysis of the causes and nature of political violence in Yobe State and Nigeria generally.

This study is also timely due to the fact that the country is presently confronted with serious security challenges. The persistent spate of bombings and series of killings going on since 2009 have claimed many lives and property worth millions of naira destroyed. The findings of this study would therefore help the government of Yobe State and Nigeria in general in finding solution to this practical political problem.

\subsection{Methodology of the study}

\subsubsection{Research design}

This study was a descriptive (survey) research having analytical elements and qualitative method. It is therefore pertinent to have a brief knowledge of the study area as explained hereunder.

\subsubsection{Study Area.}

Yobe State is a Rural State without a single cosmopolitan city with five medium sized towns with significant commercial activities located in the North Eastern part of Nigeria. It was created on $27^{\text {th }}$ August 1991 out of old Borno State by the military regime of President Ibrahim Babangida. The 2006 population census put the total population of the State at 2,432,321.

\subsubsection{Population and Sample}

The population from which samples was picked for this study is that of Yobe State. The State is varied in ethnic, tribal, and religious composition. It also has partisan loyalty and some degree of urbanization, so it can serve as a reasonably good microcosm of the nation as a whole. In this study, the sample from which data was obtained included the following groups: the political class; civil servants; the religious; traders; traditional rulers; the Academia; and Security agents.

\subsubsection{Sample Size and Sampling Technique}

The researchers choose a sample of 500 respondents from six selected Local Government Areas of the State. The Local Government Areas include: Damaturu, Fune, Potiskum, Fika, Bade and Nguru.Two Local Governments were each selected from the three senatorial zones of the State (i.e. Zone A,B and C) Out of the 500 respondents that were selected, 347 respondents correctly filled and returned the questionnaires administered. The simple random sampling techniques were employed when picking the respondents in the six 
(6) Local Government Areas. The researchers sought the help of Research Assistants that helped in the distribution and collection of the questionnaires.

\subsubsection{Methods of Data Collection}

The data for this study were collected from a well-defined questionnaire questions that were administered to the respondents in the selected Local Government Areas in the State. The secondary data for this study was collected from various sources such as: text books, government publications, magazines, newspapers, journals, and internet materials that have relevance to the study.

\subsection{Conceptual definitions Violence:}

The word violence has no precise or commonly accepted definition. The concept often serves as a catch for every variety of protest, military intervention, coercion, destruction or condemnation of people and property.

Wolf (1969 [6]) made a distinction between violence and force. According to him, violence is the capacity to impose or act of imposing one's will upon another. This imposition could be held to be illegitimate. Force on the other hand is the capacity to impose, or the act of imposing one's will upon another, where the imposition is held to be legitimate.

Collaborating this position, Nieburg (1969 [7]) also states that violence can be unambiguously defined as the most direct and severe form of physical power... it is force in action. Its use is a continuation of bargaining begun by other means, whether it is used by the State, by private groups, or by a person. He also endeavoured to distinguish force from violence. According to him, Force is a reserve capability and means of exercising power that amounts to a threat of violence or counter violence. Keane (1996 [8]) says violence is understood as any uninvited but intentional or half intentional act of physical act of physically violating the body of a person who previously had lived in peace. Ogle (1998 [9]) argues that the term violence can be used to refer to a number or different types of action. It may be purely physical, an overt individual act such as the striking of a blow or aiming of a gun, or the activity of a crowd as in the case of a mob lynching. Where ever it entails the use of material or measurable force, we may refer to it as violence. It is important to state here that Ogle does not count psychological denials of autonomy and social denials of access to opportunities such as economic and political as types of violence or inherited constraints. Ogle (1998 [10]) also emphasized that all acts of personal overt force and overt institutional force are acts of violence. In his own attempt at the meaning of violence Garver (1998 [11]) stated that violence is often connected with the use of physical force. It often involves physical force, and the association of force. Violence can occur among identifiable group of people whether tribal, ethnic, cultural, political and the like. Violence is an intricate and inevitable aspect of social change in a society. It is in fact an expression of the heterogeneity of interests, values and beliefs that arise as new formations generated by social change come up against each other.

According to Hafez (2000 [12]) situation like riots, coups, massacre, wars, pogrom, genocide, revolutions, clashes, conflicts, jihad and crusades, all fall within the ambit of violence. According to him, the etymological survey of the concept of violence may give us a clearer understanding of the word. The word "violence" comes from the combination of two Latin words: "Vis" (force) and "fero" (to carry). Also the Latin word, "violare" is itself a combination of these two words and its present participle "violans" is a plausible source for the word "violence". Thus, the etymological origin of the word (violence) has the meaning to carry force at or toward something. Earl (2004 [13]) defines violence as the use of physical force by an individual, group or organization resulting in injury or abuse to others.

In line with the above argument, Apam (2006 [14]) opined that violent conflicts generally, arise from the pursuit of divergent goals and aspiration by individuals and or groups in defined social and physical environments. They are regarded as struggles over values and claims to scarce status, power and resources in which the aim of the opponents are to neutralize, injure or eliminate their rivals.

Violence in societies are also designed to resolve divergent dualism and to achieve some kind of unity even if it were through the annihilation of one of the conflicting parties and should not therefore be regarded only in the negative or dysfunctional or disjunctive process or a breakdown of communication. He also noted that violence can come as a result of conflicts which conscious acts are involving personal or group contact and communication and a normal process of interaction particularly in complex societies in which resources are usually scarce.

Violence ranges from demonstration to rebellion against a political system or its leaders, in certain circumstances; it is directed especially against some aspects or symbols of the political system. For instance some sort of violence may involve the loss of many lives or damage to property. Apam (2006 [15]) opined that in extreme cases, it is aimed to over throw the political authorities and destroying the established political order rather than wining of concession from people in authority. In some cases, acts of violence are open to criticisms on moral grounds, but there is no complete agreement about the morality or immorality of specific political 
violence. It is worthy to mention here that individuals and groups with violent disposition often justify their action by their conviction of the absolute rightness of their demands while authorities also justify their use of violence as an absolute necessity to maintain peace and orderliness as well as the protection of ordinary citizens from intimidations.

United Nations Organization (1999 [16]) view violence as the intentional use of physical force or power threatened or actually against oneself, another person, or against a group or community, that either results in or has a high likelihood of resulting to injury, death, psychological harm or deprivation. The body went further to reveal that globally, violence takes the lives of more than 1.5 million people annually: just over $50 \%$ due to suicide, some $35 \%$ due to homicide, and just over $12 \%$ as a direct result of war and some other forms of conflict. Dzurgba (2010 [17]) identified and examined some forms of violence in societies. In order to give these forms of violence the designed impetus he described these forms of violence as: domestic violence, religious violence and political violence. According to him domestic violence occurs among spouses, children, relatives, sister-in-law, brothers-in-law and families over promiscuous behaviour, finance, property inheritance, plot, farm land and acts of incest and rape. That Domestic violence disrupts domestic unity, integration, harmony, solidarity, brotherhood and cooperation. It endangers domestic security and retards progress of individuals and families.

Religious violence occurs between two religions or two sects within the same religion over questions of belief, doctrine, scriptures, sanctuary, and piety, location of worship, territorial influence, provocative sermons, press report, misunderstanding, prejudice, hatred, discrimination, intolerance and foreign influence. Other sources of religious violence are imperial religious policy of government, urban settlements of religious groups and struggle. It is important to state here that the word violence is always prefixed with words such as domestic, religious or political. Within the context of this paper, violence would be discussed from the perspective of political violence.

\section{Political violence}

Nieburg (1969 [18]) advanced that political violence is a product of factors and actors and peoples' reactions that combine to produce violence in a society. He went further to add that political violence can also be seen as a process that takes place between various groups or categories of actors within a political system.

Gurr (1970:3 [19]) refers to political violence as "collective attacks within a political community against a political regime, its actors including competing political groups as well as incumbents or its policies". Arendt (1972 [20]) viewed political violence as an extreme behavior that is very dramatic, strongly emotive and highly visible that intends to distort general perceptions by "flooding" the senses and sensibilities of observers. The decision to use violence directly involves only a subset of the mobilized population; even in the most extreme situations, only a minority of any population is actively engaged in violent action.

The broadest definition of political violence focus on the subset of purposive acts of violence by groups that intended to increase group welfare by affecting the political relationship between groups (Communal violence) or among groups operating in the political system in general (State violence and anti State Violence). Base on the forgoing, Zimmermann (1993 [21]) offered a criterion as an effort to distinguish violence from political violence. First he took into consideration the number of people involved in a violent act. All things being equal, the probability that the acts of violence will be thought as political in nature is greater when more persons are involved in those acts. This fact should not in any way mislead people as this should not mean that if a group of people commit violent acts this becomes political violence. The motive of the act and how the community reacts to the violent act has to be seriously considered too.

The second criterion according to Zimmermann (1993 [22]) is examining the intentions of the actors and the reaction of that particular community, or the public in general. His criteria states that violent acts, whether it is simple or collective in nature would become acts of political violence.

Moser and Clark (2001[23]) see political violence as a collective sphere manifested in guerilla conflict, paramilitary conflict, political assassinations, and armed conflicts between political parties, rape and sexual abuse while Eric (2004 [24]) stated that political violence means the exercise of physical force with the intention to harm the welfare or physical integrity of the victim. According to him, the exercise of such force that is politically motivated and that can be exercised by governmental or anti-governmental groups can be described as political violence. Mifflin (2009 [25]) on his part, stated that political violence is the calculated use of unlawful violence to inculcate fear, intended to coerce or intimidate governments or societies in the pursuit of goals that are generally political, religious, or ideological. Dzurgba (2010 [26]) also advanced that political violence arises from party formation, party membership, campaign hosting, voting behaviour, pressure groups, use of thugs and assassins, recruitment and training of militias, control and use of economic resources such as petroleum oil and solid minerals, sharing of revenue, leadership, control and distribution of power, unjust electoral process, perverted judicial institution and police, indiscipline political behaviour, corruption and foreign influence. Civil war and international war are the greatest aspects of political violence. 
Political violence is a perennial feature of plural societies; in fact it has become a problem of great national and international concern because of its socio-economic and political implications. It is therefore any form of disaffection with or opposition to the procedural consensus established by a society which is calling for the total destruction of its political system. It is a purposive form of behaviour intended to disorient the behaviour of others thereby bringing about the demise of a hated social system.

\subsection{Determinants of Participation in Political Violence in Societies}

\section{Literature Review}

Several studies have been conducted throughout the globe in order to find out some of the major determinants of participation in political violence. The rationale for this is to ascertain whether education, poverty, deprivation and frustration have any causal link to political violence.

In a study conducted by Kruger (2002 [27]) to determine whether education, poverty, political violence and terrorist activities have any causal connection, the study found out that the occurrence of hate crimes is largely independent of economic conditions. Kruger (2002 [28]) analyzed data on support for attacks against Israeli targets by the Hezbollah. From the public opinion polls conducted in the West Bank and the Gaza Strip, the polls indicated that support for violent attacks does not decrease amongst those with higher education and higher living standards. The core contribution from Kruger on political violence from the statistical analysis of the determinants of participation in Hezbollah militant activities in Lebanon suggests that having a living standard above poverty line or secondary school or higher education is positively associated with participation in the Hezbollah - Israel crisis.

The study also revealed that Israeli Jewish settlers who attacked Palestinians in the West Bank in the early 1980s were overwhelmingly from high paying occupations. The conclusion speculates on why economic conditions and education are largely unrelated to participation and support for terrorism and political violence in societies. It is in this light that Nwokoma (2005 [29]) in his own attempt at the determinants of political violence in Nigeria implicated the high rate of unemployment and poverty as the main determinants of political violence in the country. According to him, the chronic shortage of employment opportunities gave the politicians the leverage to mobilize the unemployed youth for personal and parochial purposes.

Available statistics show that many of the unemployed youths turned into trained militant sects to intimidate, harass and assassinate political opponents. Nwokoma (2005 [30]) further added that the primary determinant of political violence in the Nigerian state from 1999 through 2007 was as a result of the poor and low economic growth in the country. In similar manner Piazza (2006 [31]) also carried out a study to determine whether poverty and low education are determinants of political violence activities in societies using the Rooted — in - Poverty hypothesis. According to Piazza (2006:164 [32]) the rooted-in-poverty hypothesis stems from the belief that impoverished countries teeming with poorly educated, unemployed masses qualified by a widening gap between the rich and poor combined with low literacy rates are fermentation tanks for dangerous and violent militants. The low levels of economic and social development increase the appeal of political extremism and encourage political violence and instability.

It is worthy to mention here that empirical evidence refutes this hypothesis. Yet, it continues to be popular and the belief that political violence is a result of poverty, poor education and acute unemployment. To buttress the fact that poverty cannot breed political violence from the data collected by the United States of America Department of State's office of the Coordinator for Counter Terrorism, Piazza (2006 [33]) illustrates the disparity between speculation and realty. In his study over a 15 year period, out of Ten Nations most affected or afflicted by terrorist incidences, only three fit the profile of low levels of socio-economic development.

However, from other studies conducted, evidence illustrates a starkly different reality. Research indicates that in less - developed nations economic progress is actually negatively related to transnational terrorism. It is not the poor countries but the rich ones that are more prone to transnational terrorism or political violence.

Diego and Steffen (2009 [34]) also gave their support to the fact that poverty has no relationship with political violence when they advanced that a disproportionate number of violent extremists were highly educated engineers. Piazza's studies revealed that none of the economic indicators are significant predicators of either terrorist incidents or cruelties. His study further revealed that there is no empirical evidence to support the crux of the rooted in poverty thesis. The fallout from such a revelation can be expected to be quite significant. If poverty is the critical failure point, then it also provides an easy answer to the problem of political violence, instability and terrorism in societies. Thomas (2009 [35]) in his study at the causes, responses, and the framework for discussing and preventing political violence in Kenya implicated poverty, unequal distribution of resources and land issues as the main causes of political violence in Kenya. His study revealed that there seems to be a sense among some observers that agents of political violence in Kenya are fundamentally dissatisfied with the social and economic conditions of life. Participation in political violence can therefore said to be 
furthered by a widespread sense of dissatisfaction in the distribution of wealth a situation that has given rise to high level of poverty in the country.

While Wolfenson (2010 [36]) has gone on record several times touting poverty as the main variable cause for political violence and terrorism. Underwood (2010 [37]) also disagrees and points out that most terrorist and those that engage in political violence activities are not impoverished, but rather are well educated and middle class. The case of Algeria's relative wealth and high violence is just one example that contradicts this hypothesis. Therefore, there must be some other motive for political violence outside poverty, being poor is not a sufficient motivator for violent conflict in a society. However, a major misconception still persists in the study of political violence as scholars still argues that poverty is a major determinant of political violence. Many continue to believe that poverty breeds terrorism or political violence and instability. Regardless of evidence that stand out to the contrary, the belief is not just held by the casual observer inundated with sensationalized media, but that it has also taken hold of national leaders and those leading international development agencies. As such, it is imperative to address the notion that poor people are more likely to violently revolt, engage in political violence or engage in terrorist activities.

Graeme, Neil, Christine and Jacob (2011 [38]) in examining the causes of militant violence in Pakistan frequently focused on poverty as a root cause of support for violent political groups. Moreover, much of United States of America and Western Policies towards Pakistan over the last ten years have been geared toward encouraging economic and social development as an explicit means of diminishing the terrorist threat.

Legislation before the U.S House of Representatives in April 2009, for example called for the United States to strengthen Pakistan's public education system, increase literacy, expand opportunities for vocational training and help create an appropriate national curriculum for all schools in Pakistan. Their study also revealed that the Donors Conference in Tokyo, where nearly thirty countries and international organizations pledged some $\$ 5$ billion (dollars) in development aid explicitly intended to enable Pakistan to Fight off Islamic extremism. These policies according to Graeme et al (2011 [39]) reflects a belief that poverty is a root cause of support for militancy or at least that poorer and less-educated individuals are more prone to militants' appeals. Despite the strong beliefs about links between poverty and militancy that these aggressive policy best revealed that there is little solid evidence to support this contention as earlier examined through the works of Kruger (2002), Piazza (2006), and Diego and Steffen (2009).

\subsection{Stasis of class relations and political violence in societies}

The basis of the frustration - aggression theory is found in the works of Dollard (1939) Gurr (1970) Midlarsky (1975) Anifowose (1981) and Maire (2004). They employed this approach as a general basis for the explanation of political violence in societies. This theory presents the idea of relative deprivation as a perceived disparity between value expectation and value capabilities or the lack of a need satisfaction that defines the gap between aspiration and achievement. Midlarsky (1975 [40]) simply put it this way: when there is a gap between the level of value expectation and the level of value attainment due to lack of capability to establish' a congruence between both levels, tension builds up due to the unfulfilled aspiration or an unsatisfied urge or need. This when not arrested in time, leads to frustration. Frustration, when it builds up leads to the rising up of suppressed emotions of anger which is often directed against the party considered to be the source of deprivation or dissatisfaction. This strong emotion finally finds an outlet through aggressive and invariably violent disposition towards the environment. Anifowose (1982 [41]) in his own attempt at looking at the stasis of class relations as a cause of political violence in societies, used his theoretical postulations i.e. (the modernization theory and the frustration - aggression theory) to state that there is a paradoxical relationship between modernization and political disorder. According to him, developed and affluent nations provides a model that produces stability and modernization in societies, while developing states produces instability. His study also shows that the processes of modernization in Nigeria undoubtedly gave rise to cleavages and political conflict (such as those between the economically developed South and the more backward North). These cleavages and conflicts between the two areas were the result of the lack of proper understanding of the concept and advantages of interdependence in a federal system by the Northern and Southern politicians in Nigeria. Again his study revealed that a society in which the modernizing leaders are committed to a rapid expansion in the number of educated persons within the population but where there is no corresponding increase in the level of economic opportunities is most conducive to political unrest.

However, Anifowose (1982 [42]) studies on Violence and Politics in Nigeria: The Tiv and Yoruba experience show that the causes of the Tiv Riots of the 1960s and the disturbances in Western Nigeria in 1965 were varied and complex. His study revealed that the two cases of misgiving against what was perceived to be an oppressive regime erupted into violence. He used these cases to test empirically the theoretical models of political violence (Frustration - Aggression) theory. The study revealed that the frustration - aggression theory have limited explanatory value in the understanding of the cause or causes of political violence in Tiv and Yoruba cases. For while frustration, anger and the perception of deprivation and injustice did undoubtedly 
affect the attitude of the Tiv and Yoruba people towards authority and therefore, increased the chance and intensity of violence, these factors are not in themselves sufficient to explain why violence occurred in the first place in Tiv land. Anifowose (1982) studies further revealed that whether or not a group resorts to the use of violence as a mechanism for redressing grievances also depends on the political and socio-economic circumstances prevailing at the time. That certainly traditions of violence, the "natural anarchism" of a group or their beliefs about violence seemed to be of minimal importance in explaining why violence does in fact occur.

Muller accepted the classical hypothesis of Karl Marx as an analytical tool for explaining the causes of revolutions in societies. As Muller (1985 [43]) quoting De Tocqueville (1835) rightly articulated: Almost all of the revolutions which have changed the aspects of nation have been made to consolidate or destroy social inequality.

Tocqueville further maintained that even at the instance of improvement of natural conditions of men and women, there are other preconditions capable of engendering violence and tension in the polity. To him:

It is not always by going from bad to worse that a country falls into a revolution. It happens most frequently that a people which has supported the most crushing laws without complaint and apparently as if they were unfelt throws them off with violence as soon as the burden begins to be diminished. The state of things destroyed by revolution is almost somewhat better than that which immediately preceded it, and experience has shown that the most dangerous moment for a bad government is usually when it enters upon the work force of reform. The evils which were endured with patience so long as they were inevitable; seem intolerable as soon as a hope can be entertained if escaping from them. The abused which are removed, seem to lay bare those which remain and to render the chances of them more acute, the evil has decreased, it is true, but the perception of the evil is keener (quoted in Adebanwi, 2004:328 [44]).

The view elucidated above by Muller was strongly debunked by Sigelman and Simpson. They both disagreed with Karl Marx's classical hypothesis which stated that economic inequality is the cause or causes of conflicts in a society. Their study revealed that the traditional elegance of Karl Marx's classical hypothesis does not stand up to empirical scrutiny for vast inequalities that persist in many countries without significant recourse to violence. Berkowitz (1988 [45]) was also in a similar frame of mind when in his study he demonstrated that men are most inclined to aggression when subjected to unjustified or sustained frustration. The feeling of deprivation and frustration occur amongst individuals and group in societies as a result of the competition for space when their expectations are not met.

Apter (1997 [46]) stated that political violence is a constant pattern that has been present throughout the history of humanity. The overthrow of tyrannical systems and regimes, the desire for a separate and independent state, the tendency to impose one's religious belief on other to establish state religions and ideologies, an intrigue and to gain access to power by devious as well as institutional means are all as old as human kind. The destruction and chaos provoked by the means used by perpetrators of political violence have origins in diverse motivations that fluctuate from the desire to defeat a government to the desire to control a region or a land. Likewise, opposite motivations such as religious beliefs and economic interests coincide in the use of violence to achieve power.

Many Scholars have carried out studies on the causes and motivations of political violence in societies. For instance (White 1978, Tilly 1978, Thomson 1989, Otite 1990, and White 1993) all carried out research that agreed with Karl Marx's classical hypothesis that postulated that the underlying cause of domestic political violence is economic inequality.

Violence in any society is in fact coterminous with the conflict of interests and competition for space as well as those of scarce resources. It is only natural that when we observe the lives of men, and of course, women around us, we cannot fail to be struck by two contending facts; that as a rule, every man desires to have his own way, to think and act the way he likes. As Marx 1880 cited in Erunke (2004 [47]) observes that the history of all hitherto existing societies is a history of class struggle between the class that controls property and those that do not; between the Patrician and the Plebian; Lords and Serfs; slaves and their Masters; Bourgeoisie and proletariat, all of whom are antagonistic of one another in competition for space. Obadare (1999 [48]) also gave credence to the frustration - aggression - violence mode when looking at the causes and utility of political violence in contemporary Nigeria. The source of frustration in South Western Nigeria was the annulment of the $12^{\text {th }}$ June 1993 elections, capped a litany of political malfeasance by the Babagida's regime. Gurr's theory is also useful to the extent to which it can explain why initial reaction to the news of the annulment was more truculent in the western part of the country. In Nigeria the sense of deprivation the (annulment) was arguably more intense among the Yorubas, the dominant ethnic group in western Nigeria from where the acclaimed winner Moshood Abiola, the presumed winner of the elections came from. Yet, the violence which followed the annulment is also illustrative of a much deeper malaise in the Nigerian polity. The inveterate intolerance of dissent manifested in the contestation of space for popular participation; the exclusion of unfavoured groups 
from the conduct of running of the government and the blocking of traditional channels for ventilating social grievances all motivated violence in the Western part of the country.

The armed struggle, the persistent conflict and insurgency in the Niger Delta all of which have been subsumed under the general term Niger Delta crises may be seen from the dimension of the frustration aggression hypothesis. Militant youths directed violence against the Federal Government of Nigeria and Multi National Corporations carrying out exploration and mining of crude oil in the Niger Delta. Their struggle was basically an agitation for the development of the Niger Delta Region, attainment of political goals, Freedom from poverty, degradation, unemployment and the like. They anchor their demands through indiscriminate killings, kidnapping activities and attacks on oil and other business facilities in the region. Mair (2004 [49]) on his part contended that the potential for collective violence varies strongly with the discrepancy between what they think they deserve and what they think they will get, there is a likely hood of rebellion. That just as frustration produces aggressive behaviour on the part of an individual, so does relative deprivation predict collective violence by social groups. Williams (2004 [50]) and Erunke (2008 [51]) also added that every man's interest conflicts in certain regular ways with those of other men and hence breads contempt that subsequently leads to conflicts. This notion therefore rejects a balanced society at whatever level of analysis while arguments abound that conflict is a universal condition which occurs in any form in a society be it a backward or forward society. Garver (2004 [52) clearly supported the frustration - aggression hypothesis when he opined that: "the institutional form of violence operates when people are deprived of choices in a systematic way by the very manner in which transactions normally take place". Exploring the causes of political violence entails the analysis of the different domains and levels within which violence emerges.

Suich (2008 [53]) also used the frustration aggression hypothesis to discuss the recent political violence that took place in Kenya. According to him, the sidelining of the rule of law in contexts of competing for political power, the impunity for both instigators and a political tradition that has in many cases, implied the forming of a government is deemed essential for obtaining access to resources cannot stand alone as explanations of political violence. Socio-economic factors such as widespread poverty unequal distribution of resources, high unemployment rates and land disputes have been pointed out to as the root causes of political violence in Kenya. The agents of political violence in Kenya are fundamentally dissatisfied with the social and economic conditions of life. Kenya has an estimated two million unemployed youth that joining a gang may for some be seen as "a way of life" that can increase possibilities. When these gangs engage in political violence members are sometimes promised payment for their activities and also less organized perpetrators can benefit from looting. Participation in political violence is said to be furthered by a widespread sense of dissatisfaction in the distribution of wealth. Distribution of wealth is extremely unequal in Kenya. According to the Society for International Development 2004 Kenya is the $10^{\text {th }}$ most unequal country in the world as the richest 10 percent of the population controls 42 percent of the country's wealth, while the poorest 10 percent own less than 1 percent.

Access to resources varies highly from region to region. With these lenses, political violence is a way of demonstrating dissatisfaction with the cruel conditions of life that stand in contrast to the elite's comfortable way of life which is perceived by the poor to result from political connections and corruption.

\subsection{Power contention and political violence in Nigeria}

Hypotheses to explain cross - national variation in levels of rebellion and causes of political violence can also be grounded principally on the power contention theory. To evaluate the validity of this competing theory comparable macro societal research were conducted to support the predictions of the power contention model. For instance, various sources point to the frequency of violence during election time in Nigeria. Human Right Watch 2002 carried out an empirical investigation on political violence before the 2003 round of elections. It underlined the important role of violence in determining political outcomes in many specific Nigerian States.

A determinant of election time violence was found out to be electoral behaviour, while simultaneously exploring potential avenues to counteract it on policy grounds. A randomized intervention research designed with the support of a Network of Non- Governmental Organizations (NGOs) headed by the Action Aid International Nigeria randomly distributed questionnaires to set of locations (States) with history of electoral violence and a similar set of locations serving as control group.

The aim of the research were to determine the exogenous variations in political motivation for violence and to include voters to react differently to violence and lastly studying political violence as an exogenous determinants of voting behaviour and analyzing effects of connectedness between subjects exposed to the campaign (social networks). From the findings of the research, it was revealed that politicians who wanted to access power and resources by all means incited their supporters to cause conflict in the society particularly during campaigns. In fact election related violence has negative impact on election outcomes. Most voters tend to vote for politicians that are violently inclined. Electoral violence influences the attitude and behaviour of voters during and after elections as shown in the study. According to Takirambudde (2002 [54]) some of the 
worst violence took place during the primaries of the ruling Peoples' Democratic Party (PDP) particularly in the oil producing State of Bayelsa. In the far North and the North Central States politicians have also used religion and ethnicity to galvanize political support or opposition stirring up sentiments that could spark further communal violence in Nigeria, as evidenced in the so called Miss World Riots in Kaduna in November 2002 and the Jos carnage in 2009.

In the same vein, the Human Rights Watch 2002 and the Campaign Against Electoral Violence in Nigeria (CAEVIN) embarked on a collaborative research project between Action Aid in Nigeria and the University of Oxford embarked on a research that was borne out of the fact that violence has continually marred past elections in Nigeria. They carried out the research to examine the attitudes that promotes electoral violence. The study found out that the "do-or-die" approach to politics as a means of accessing power and resources is a common feature amongst Nigerian politicians. This "do or die" attitude of politicians affects voting pattern greatly according to the research. To measure the attitude of political violence in Nigeria six States namely: Oyo, Lagos, Plateau, Kaduna, Rivers and Delta were selected taking into consideration the dynamics of conflicts and electoral violence in the States before selecting the States, the trend of violence in these states were also considered. The Network of Activist Scholars of Politics and International Relations (NASPIR) in 2004 also carried out a study to uncover the embedded nature of most conventional scholarship on political violence. They also advanced that elite power struggle in states motivates political violence and terrorism. That terror is deeply embedded in the elite power struggle, in societies.

From the above discourse, it can be seen that Nigerian politicians have always used violence as a tool to acquire or retain political support, wealth and influence. Voters in Nigeria are most often than not intimidated and silenced. Politicians can stand for office without fear of bloodshed. Erunke (2008:138 [55]) amplifying Thomas Hobbes argument for the cause of political violence in societies, traces the origin of violence among men to their natural equality. He writes: "Nature has made men so equal in the faculties of body and mind --(that) the difference between man and man is not so considerable so that one man could there upon claim to himself any benefit to which another may possess". Given this equality they all feel that they have same hope of acquiring these benefits. Competition arises and with this, enmity. In Hobbes words: and therefore, if any two men desire the same thing which they nevertheless they cannot both enjoy they become enemies. The result is an attempt to subdue one another.

It is clear from the forgoing that the perspective of conflict is relevant to the socio-economic and political development and, hence central to social change in the society. Conflict in Nigeria, however, has been attributed to the class divide between the haves and the have-nots. Thus the concept of class here is used to explain the various social formations and relations that characterize the Nigerian system. For instance, the system comprises the political elite and the down-trodden masses. The former is so blessed with the paraphernalia of government tools and so, keeps custody of the nation's common wealth. The latter groups do not necessarily possess the influence, so, the ensuing bitterness between these two groups propels conflict.

In a more complex dimension, the conflict situation as stated above is either stirred up by the elite class in order to win cheap political goals; or it is simple that conflicts emanates out of peoples' disconnect from the corridors of power and the ensuring rising frustration that follows. Either ways however, argument abound that the ongoing tension in Nigeria is an off shoot of an environment that is inconsistent with civilized practices, a system that is simply hostile and practically insensitive to the plight of teeming Nigerians at the expense of a few comprador bourgeoisie class.

The above scenarios informs or buttress the vulnerability of the Nigerian system that is unequivocally characterized by several belligerent groups that have attempted to show their discontents on high level injustices perpetrated by Nigerian politicians in recent times.

\subsection{Theoretical framework}

Hypotheses that explains political violence or conflicts in societies are principally grounded in the Conflict Theory (Dahrendorf, 1969), Frustration - Aggression Hypothesis (Gurr, 1970), Modernization Theory (Apter, 1989), Huntington (1990), the Rational Choice Theory), (Hafez, 2004) Rooted-in-Poverty hypothesis and Political Contention Theory (Piazza 2009) and the like. The researcher thus used the Social Movement Theory as the main theoretical approach for this study.

\subsection{Social movement theory}

Hafez (2005 [56]) advances that the study of political violence by applying the Social Movement Theory (SMT) as a means of explaining the conditions under which political violence occurs in societies. The Social Movement Theory is an interdisciplinary approach to the study and contention that focuses on the underlying mechanism of collective violence. It helps to explain how group protest in a society and what motivates their actions and inaction. The theory's strength comes from its three variables: 


\section{i. $\quad$ Resources mobilization; \\ ii. Political opportunity; and \\ iii. Ideological framing.}

Hafez used this hypothesis to study the causes and motivations of political violence in North Africa specifically in Algeria and Morocco. According to him, the real motivating grievances of groups in societies centers on their town, state and their local economy. These groups also use their social interaction to provide for the population, recruit followers and propagate their ideology. The theory also explains how regimes method of repression and poor governance practices can fuel or smother political violence. According to this exponent, the relevant influences for the movement and the array of political opportunities it benefit and also the level of exclusion from the political system plays a powerful role in radicalizing movements in such societies.

Within the context of resources mobilization hypothesis, the theory starts from the very straight forward observation that all political action is socially structured and that the resources available to activists are patterned accordingly. It makes the assumption that movement activist are at least as calculatively rational as they are more conventional political actors and that they will accordingly devise strategies of action which make best use of the resources they have and which minimize the requirement for resources they do not have. The weakness of this theory is that only radical individuals and groups that want some form of recognition mobilizes their members to resist the State based on ideological grounds.

\section{Data presentation and analysis}

\subsection{Table 1 Respondents Demographic data}

\begin{tabular}{|l|l|l|}
\hline Gender & Frequency & Percentage \\
\hline Male & 220 & $63.5 \%$ \\
\hline Female & 127 & $36.5 \%$ \\
\hline Total & 347 & 100 \\
\hline
\end{tabular}

Source: field survey 2013

A total of 347 questionnaires were obtained from the data collection process and analyzed for this research. The respondent population comprised $63.5 \%$ males and $36.5 \%$ females, thus the gender distribution amongst the respondents can be considered balanced.

Table 2 demonstrates the literacy status for both male and female respondents

\begin{tabular}{|l|l|l|l|l|l|l|}
\hline Education & Illiterates & Primary & Secondary & Tertiary & Total & Percentage\% \\
\hline Male & 20 & 60 & 102 & 40 & 220 & $63.5 \%$ \\
\hline Female & 40 & 20 & 54 & 13 & 127 & $36.5 \%$ \\
\hline Percentage (\%) & $17.2 \%$ & $23.5 \%$ & $44.1 \%$ & $15.2 \%$ & 347 & $100 \%$ \\
\hline
\end{tabular}

Source: field survey 2013

Table 2 above shows the literacy status of respondents in Yobe State. Both Male and female illiterate respondents constitute $17.2 \%$ of the population. $23.5 \%$ constituted the population with primary education. Respondents with secondary education had the highest percentage $(44.1 \%)$ while respondents with tertiary education constituted $15.2 \%$ of the general population.

Table 3 Demonstrate the causes of political violence in Yobe State.

\begin{tabular}{|l|l|l|l|}
\hline S/N & Variable & No of respondents & $\%$ \\
\hline 1 & Religious & 58 & $16.7 \%$ \\
\hline 2 & Ethnicity & 47 & $13.6 \%$ \\
\hline 3 & Politics & 110 & $31.7 \%$ \\
\hline 4 & Poverty & 70 & $20.2 \%$ \\
\hline 5 & Unemployment & 62 & $17.8 \%$ \\
\hline 6 & Total & 347 & $100 \%$ \\
\hline
\end{tabular}

Source: field survey 2013.

The Table above shows that 58 respondents representing 16.7\% of the entire Yobe population were of the view that the cause of political violence in Yobe State is religion.47 (13.6\%) respondents were of the view that the causes of political violence in the state was as a result of ethnicity. $110(31.7 \%)$ respondents were of the view that the causes of political violence was as a result of politics. $22.2 \%$ believed poverty motivated violence in the state while $17.8 \%$ thought employment was the cause of political violence in Yobe State. 


\section{Socio-economic impact of political violence in Yobe State}

Table 4 Does political violence affect level of investment?

\begin{tabular}{|l|l|l|}
\hline Response & No of respondents & Percentage (\%) \\
\hline Yes & 215 & 61.9 \\
\hline No & 132 & 38.1 \\
\hline Total & 347 & $100 \%$ \\
\hline
\end{tabular}

Source: field survey 2013

The Table above shows that political violence affects level of investments in a society. It can therefore be put forward that since 2009 the level of investments in Yobe State has dropped drastically as a result of political violence thus affecting the socio-economic development of the State and the country generally.

Table 5 Demonstrates budgetary cost of managing political violence in Yobe State.

Source: field survey 2013

\begin{tabular}{|l|l|l|}
\hline Variable & No of respondents & $\%$ \\
\hline Very high & 200 & 57.6 \\
\hline High & 90 & 25.9 \\
\hline Undecided & 7 & 2.2 \\
\hline Very low & 40 & 11.5 \\
\hline Low & 10 & 2.8 \\
\hline Total & 347 & 100 \\
\hline
\end{tabular}

Table 4 above shows the budgetary cost of managing the crises in the State. And from the data gathered, 200 respondents (57.6\%) believed that the cost of managing political violent related crises were very high. $25.9 \%$ also agreed that the budgetary cost was high. $2.2 \%$ were undecided on the issue. $11.5 \%$ of the population were of the view that budgetary cost was very low while $2.8 \%$ believed that the budgetary cost of managing political violence is low.

\section{Float chart I}

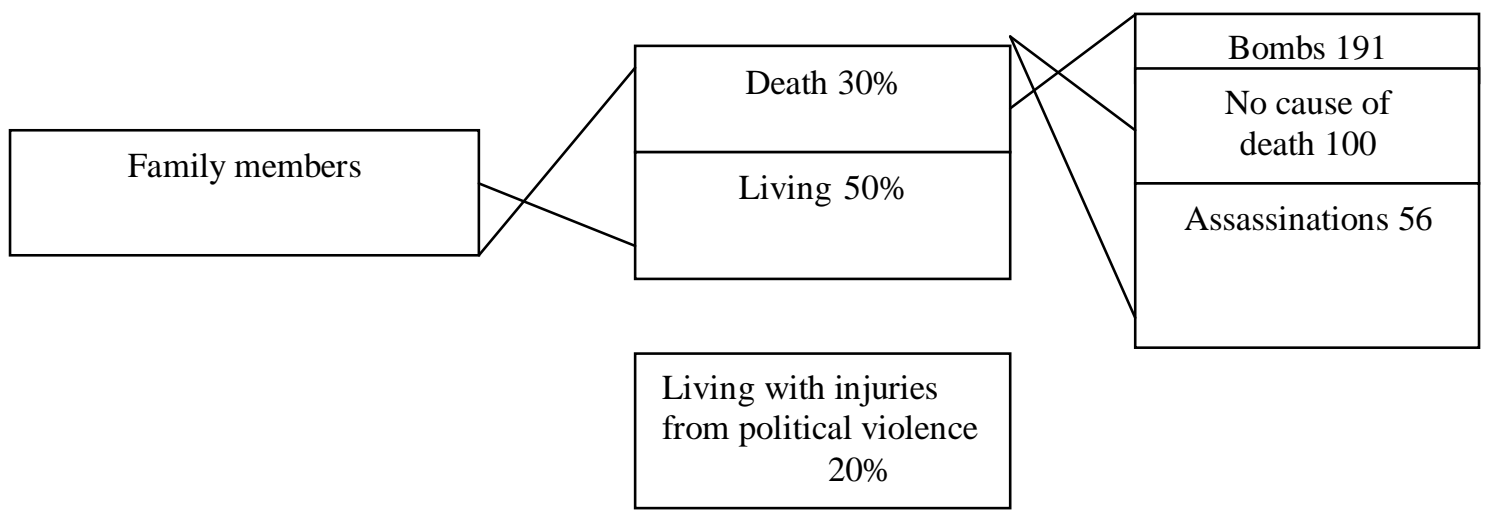

Effect of political violence on households in Yobe State. The Chart is base on the field survey conducted by the researchers.

The flow chart examined the effect of political violence on households in Yobe State. The Chart shows that $30 \%$ of the population of the State lost their lives as a result of politically related violence while $20 \%$ were living with various degrees of injuries from political violence. It is important to state here that most of the victims died as a result of bomb blasts and assassinations while other causes of death in the State were unknown.

\section{Discussion, Conclusion and suggestions}

From the study conducted in the six Local Government Areas of Yobe State, the researchers found out that the cause of political violence is attributed to leadership failure in the State but not poverty or unemployment. More so many respondents were of the view that the deteriorating security situation in Yobe State to came as a result of political violence that is why Ernie (2008:138 [58]) amplifying Thomas Hobbes argument for the cause of political violence in societies, traces the origin of violence among men to their natural equality. He writes: "Nature has made men so equal in the faculties of body and mind --- (that) the difference between man and man is not so considerable so that one man could there upon claim to himself any benefit to which another may possess". Given this equality they all feel that they have same hope of acquiring these benefits. Competition arises and with this, enmity. In Hobbes words: and therefore, if any two men desire the 
same thing which they nevertheless they cannot both enjoy they become enemies. The result is an attempt to subdue one another.

It is in line with the above view that Hafez's Social movement hypothesis validates the causes and motivations of political violence in a society such as Nigeria. A society where poor governance practices; limited political and economic opportunities have radicalized the local population in the State. Findings further revealed that the level of funding for the management of the crises has increased thus affecting the development of key sectors like education and health.

Based on the foregoing findings it can be said that political violence has socio-economic consequences on the people as such the following suggestions would help in solving the question of political violence in Yobe State and Nigeria generally.

1. Political leaders should play a role in building effective government through their constitutional duties and mandates. The core of the crises in Yobe State is the inability of political leaders to adhere to good governance practices.

2. Political leaders should be honest and transparent when spending public funds.

3. Government of Yobe State should initiate good pro-poor policies that would help in reducing the high level of poverty and unemployment in the State and Nigeria at large.

4. The Yobe State Government should endeavour to satisfy all competing interest, competing for the control of political and economic power by introducing measures or policies that would carry every one along in the state.

\section{References}

[1]. A. Rochester and D. Pearson, A comparative study of civil strife In H.D Hugh (ed.) Violence in America: historical and comparative perspective (Washington, Govern Press 1984)

[2]. R. Douglas, The Human Right to Peace (Mumbai, Better Yourself Books 2003)

[3] Ibid

[4] I. A. Gambari Challenges of conflict resolution and the role of Nigeria in regional and global peace and security ( National Defence College Nigeria Graduation Lecture Series No.13 August 2008)

[5] H. Mohammed Nigeria's convulsive federalism: perspectives on flashpoints of conflict in Northern Nigeria (Ibadan Cypress concepts and solutions ltd 2012)

[6] R.P Wolf, On violence. Journal of philosophy .66(19)1969 pp602-606

[7] N.L Nieburg Political violence: the behavioural process (New York st.martins press 1969)

[8] D. Keane The economic functions of violence in civil war Adelphi Paper (London: international Institute for strategic studies 1998)

[9] Ogle Violence defined in terms of physical force in J.M.G Van der Dennen (ed.) theories of political and social violence ( New York Free press.2004)

[10] Ibid

[11]. Garver Violence defined in terms of physical force in J.M.G Van der Dennen (ed.) theories of political and social violence (New York Free press.2004)

[12] M.M Hafez Armed Islamist movements and political violence in Algeria. The Middle East Journal 54(4) 9Autum 2000) 584

[13] J .Earl Tanks, Tear gas and taxes: toward a theory of movement repression. Sociological theory 21(1)44-68

[14] J.I Apam, Ethno-Religious Conflicts and Governance in Nigeria. PhD Thesis. Department of Political Science University of Jos. (Unpublished Material 2006)

[15] Ibid

[16] United Nations. International convention for the suppression for the financing of terrorism (United Nations: New York 1999)

[17] A. Dzurgba, Prevention and resolution of conflict: local and international perspectives (Ibadan, John Archers Press 2010)

[18] N.L Nieburg, political violence: the behavioural process (.New York, st.martins press pp 10-15 1969)

[19]. T.R Gurr, Why Men Rebel: (Princeton: Princeton University Press 1970)

[20]. C. Arendt and A. Hannah, Crises of the Republic (New York, Harcourt Brace Jovanovich Inc 1996).

[21]. E. Zimmerman, Political violence, Crises and Reflections: Theories and Research. (Cambridge: Schenkman Publishing Co. 1983)

[22]. Ibid

[23]. A Moser and F. Clark, Victims perpetrators or actors? Gendered arm conflicts and political violence (New York: St. Martin's Press.2001)

[24]. N. Eric, The impact of political violence on tourism: dynamic cross national estimation (New York, NY Press 2003)

[25]. H. Mifflin The American Heritage Dictionary of English Language NY: Mifflin Publishers 2009

[26]. A. Dzurgba, Prevention and resolution of conflict: local and international perspectives (Ibadan: John Archers Press 2010)

[27]. A.B Krueger, Education, Poverty, Political Violence and Terrorism: Is there a causal connection? Journal of Economic Perspective 17(4). 2002 pp. $119-144$

[28]. Ibid

[29]. N.I Nwokoma Nigerian policy reform programme from 1999 to date: a socio-economic perspective. (A paper presented at a seminar organized by the independence policy group held in Abuja April 2005) 7

[30]. Ibid

[31] J. Piazza, Terrorism, Poor Economic Development and Social Cleavages. Journal of Terrorism and Political Violence 18 (1) p.160. 2006

[32]. Ibid

[33]. Ibid

[34]. G. Diego and H. Steffen Why are there so many engineers among Islamic radicals? Euopean Journal of sociology 50(2) 201-210

[35]. O.H Thomas, O.H. A Study of Political Violence in Kenya accessed 20th May 2011 from http://www.newsweek.com/id/84257 2009

[36]. J. D Wolferson On peace and poverty: Ten years at the bank accessed September 2012 from htpp.www.discussworldbank.org/content/interview/Detail/2058 2005 
[37]. J. Underwood On peace and Poverty Ten years at the bank accessed September 2012 from htpp.www.discussworldbank.org/content/interview/detail/2058 2005

[38]. B. Graem, C.F Christine, M. Neil, and N.S Jacob, Poverty and Support for Militant Politics: Evidence from Pakistan. (Princeton, Princeton University Press 2011)

[39]. Ibid

[40]. M. Midlarsky On war ( New York Free press 1975)

[41]. R. Anifowose, Violence and politics: the Tiv and Yoruba experience (New York: Nok Publishers International.1982)

[42]. Ibid

[43]. J. Muller, The remnants of war: thugs as residual combatants (Mimeo Ohio State University 2001)

[44]. S. Akinrinade Ethics and religious conflicts in Nigeria: what lessons for South Africa? Strategic Review Southern Africa 22(2) 2000 48-75

[45]. L.Berkowitz, Aggressive: A social Psychological Analysis (New York: McGraw Hill 1962)

[46]. D. Apter, the legitimization of violence. (London: Macmillan. Press 1996)

[47]. C.E Erunke, The 2007 general elections and survival of Nigeria's fourth republic. Journal of Modern Society 1(2) pp. 132-141. 2008

[48]. E. Obadare, Democratic Transition and Political violence in Nigeria. Journal of Africa Development 1(2) pp. 202-215, 1999.

[49]. A.Maire Aggression: beyond intractability. Retrieved 24th July, 2012 frohtpp://www.beyondintractability. Org/essay/aggression 2004

[50]. A. Williams, towards the transformation of Nigeria: a jubilee elite infamy. Address presented to a group of Nigeria professionals as part of Nigeria's 43rd Independence Anniversary. Albany Georgia, USA. October 1. 2003

[51]. C.E Erunke, The 2007 general elections and survival of Nigeria's fourth republic. Journal of Modern Society 1(2) pp. 132-141. 2008

[52]. Garver Violence defined in terms of physical force in J.M.G Van der Dennen (ed.) theories of political and social violence (New York Free press.2004)

[53]. A Suich, Beyond tribalism: Kenya's violence is not about ethnicity. Age and poverty as factors too. Accessed $20^{\text {th }}$ May 2011 from http//www.newsweek.corn!id/84257.2008

[54]. P. Takirambudde Nigeria: political violence and elections 2003 accessed April 2011 from www.Africa.uppen.edu/urgent/action 2003

[55]. C.E Erunke, The 2007 general elections and survival of Nigeria's fourth republic. Journal of Modern Society 1(2) pp. 132-141. 2008

[56]. M. M Hafeez, From marginalization to massacres: a political process explanation of violence in Algeria in W. Duintan, (ed) Islamic activism: A social movement theory approach. (Bloomington and Indianapolis: Indiana University press 2004) 